\title{
THE PAST IS EVIL/EVIL IS PAST: ON RETROSPECTIVE POLITICS, PHILOSOPHY OF HISTORY, AND TEMPORAL MANICHAEISM
}

\author{
BERBER BEVERNAGE ${ }^{1}$
}

\author{
ABSTRACT
}

One of the most remarkable phenomena in current international politics is the increasing attention paid to "historical injustice." Opinions on this phenomenon strongly differ. For some it stands for a new and noble type of politics based on raised moral standards and helping the cause of peace and democracy. Others are more critical and claim that retrospective politics comes at the cost of present- or future-oriented politics and tends to be anti-utopian.

The warnings about the perils of a retrospective politics outweighing politics directed at contemporary injustices, or strivings for a more just future, should be taken seriously. Yet the alternative of a politics disregarding all historical injustice is not desirable either. We should refuse to choose between restitution for historical injustices and struggle for justice in the present or the future. Rather, we should look for types of retrospective politics that do not oppose but complement or reinforce the emancipatory and utopian elements in present- and future-directed politics.

I argue that retrospective politics can indeed have negative effects. Most notably it can lead to a "temporal Manichaeism" that not only posits that the past is evil, but also tends to treat evil as anachronistic or as belonging to the past. Yet I claim that ethical Manichaeism and anti-utopianism and are not inherent features of all retrospective politics but rather result from an underlying philosophy of history that treats the relation between past, present, and future in antinomic terms and prevents us from understanding "transtemporal" injustices and responsibilities.

In order to pinpoint the problem of certain types of retrospective politics and point toward some alternatives, I start out from a criticism formulated by the German philosopher Odo Marquard and originally directed primarily at progressivist philosophies of history.

Keywords: historical injustice, transitional justice, retrospective politics, post-histoire, politics of time, progress, ethics

"If we can reframe our history to include both perpetrators and victims as victims of the ultimate perpetrator-namely, the conflict of the past, we will have fully achieved unity and reconciliation. ..."2

1. I would like to thank Egon Bauwelinck, Tessa Boeykens, Lore Colaert, Antoon De Baets, Hannah Franzki, Lucian Hölscher, Pieter Lagrou, Gisele Iecker de Almeida, Chris Lorenz, Gabrielle Spiegel, Kenan Van De Mieroop, and Chiel van den Akker for their stimulating comments and critiques, which greatly helped me in writing this article.

2. Commissioner Wynand Malan in his minority position in: South African Truth and Reconciliation Commission, Final Report (Cape Town, 1998), V, 443. 


\section{INTRODUCTION}

One of the most remarkable current political phenomena is undoubtedly the increasing international attention paid to recent and less recent "historical injustices." Since the early 1990s we have seen the rise of an impressive number of different initiatives that address all kinds of historical evils, ranging from primarily (though not solely) symbolic acts such as memorialization programs, truth commissions, and public apologies, to more practical political measures such as reparation payments and historical redress, to straightforward judicial prosecutions through tribunals and (inter)national courts. Some of these initiatives are well-known or have even become thoroughly iconic: think, for example, of the restitution to victims of the Holocaust, the prosecution of war criminals, public apologies to indigenous peoples by (former) colonial powers, the ongoing debate on reparations for slavery, and so on. ${ }^{3}$

Along with numerous less-known cases, these historical-justice initiatives have become the central focus of intense intellectual discussions both within and outside the academic sphere. Most commentators agree that the initiatives thoroughly characterize contemporary international politics, and several labels have been coined to describe approximately the same phenomenon: some speak about the rise of "historical justice," others about "politics of regret,"5 and still others about "reparation politics,"6 or as I will do here, "retrospective politics."

When it comes to assessing the precise political, sociocultural, or ethical meaning of the focus on historical injustice and the rise of retrospective politics, however, opinions strongly differ. For some, the phenomenon represents a new and noble type of politics that strives for higher moral standards, breaks with the realpolitik of the past, and helps the cause of justice, peace, and democracy. According to Tuomas Forsberg, the idea that we cannot simply leave the past behind but must carry the burden of history represents a genuine "cultural turn" in political science. ${ }^{7}$ The Nigerian Nobel Prizewinner Wole Soyinka speaks about a "fin de millénaire fever of atonement" and praises (certain) reparation initiatives as offering possibilities for a symbolic new beginning or even a "Global Annulment" of debts and historical injustices. "Reparations," Soyinka claims, "serve as a cogent critique of history and thus a potent restraint of its repetition." Elazar Barkan, one of the most optimistic spokesmen in the field of transitional justice,

3. For a good overview of these kinds of initiatives, see Dinah Shelton, "The World of Atonement: Reparations for Historical Injustices," Miskolc Journal of International Law 1, no. 2 (2004), 259-289.

4. Ruti Teitel, Transitional justice (Oxford: Oxford University Press, 2002).

5. Jeffrey Olick, The Politics of Regret: On Collective Memory and Historical Responsibility (New York: Routledge, 2007).

6. John Torpey, Making Whole What Has Been Smashed: On Reparation Politics (Cambridge, MA: Harvard University Press, 2006).

7. Tuomas Forsberg, "The Philosophy and Practice of Dealing with the Past: Some Conceptual and Normative Issues," in Burying the Past: Making Peace and Doing Justice after Civil Conflict. Expanded and updated, ed. Nigel Biggar (Washington, DC: Georgetown University Press, 2003), 58.

8. Wole Soyinka, The Burden of Memory, the Muse of Forgiveness (Oxford: Oxford University Press, 1999), 83. 
even claims that the increased international sensibility to the need for restitution to "past victims" and the "willingness of nations to embrace their own guilt" since the 1990s represents nothing less than the rise of a "new globalism" based on an "expanded international moral standard" or even a "neo-enlightenment morality."

Yet not everybody shares the optimism of people like Soyinka and Barkan. Some commentators claim that retrospective politics often comes at the cost of present and future oriented politics or argue that it tends to be anti-utopian and can therefore hardly be called emancipatory. One of the best-known defenders of this argument is John Torpey, who laments that " "coming to terms with the past' in contemporary politics has extensively supplanted the elaboration of visions of the future." ${ }^{10}$ Reparations politics, he argues, is often merely a tactical move that characterizes a historical era that is no longer capable of offering "inclusive visions of progressive change," as, for example, represented by socialism or the American civil rights movement. Sadly, Torpey remarks, the only road to the future in contemporary politics seems to run via the long detour of the disasters of the past. ${ }^{11}$

Torpey is certainly not the only intellectual expressing these worries. According to historian Pieter Lagrou, "our contemporary societies, for lack of future projects, shrink into a 'passeist' culture."12 In European public discourse, he argues, the focus on crimes of the distant past has become so strong that it tends to marginalize claims of victims of contemporary crimes and human rights violations. Therefore, Lagrou argues, "a commemorative discourse of victimhood is very much the opposite of a constructive and dynamic engagement with the present, but rather a paralyzing regression of democratic debate."13 Lagrou's argument closely resembles many others that turn against retrospective politics and "victim culture" such as Ian Buruma's warning about the peril of minorities defining themselves exclusively as historical victims and engaging in an "Olympics of suffering" 14 and Charles Maier's claims about a "surfeit of memory." 15

9. Elazar Barkan, The Guilt of Nations: Restitution and Negotiating Historical Injustices (Baltimore: John Hopkins University Press, 2000), and Elazar Barkan, "Restitution and Amending Historical Injustices in International Morality," in Politics and the Past: On Repairing Historical Injustice, ed. J. Torpey (Oxford: Rowman \& Littlefield Publishers, 2003), 91-102.

10. John Torpey, "Introduction," in Torpey, ed., Politics and the Past, 1.

11. John Torpey, "Making Whole What Has Been Smashed: Reflections on Reparations," Journal of Modern History 73, no. 2 (2001), 333-358.

12. Pieter Lagrou, "De l'histoire du temps présent à l'histoire des autres: Comment une discipline critique devint complaisante," Vingtième Siècle: Revue d'histoire 118 (2013), 117. [My translation]

13. Pieter Lagrou, "Europe as a Place for Common Memories? Some Thoughts on Victimhood, Identity and Emancipation from the Past," in Clashes in European Memory: The Case of Communist Repression and the Holocaust, ed. Muriel Blaive, Christian Gerbel, and Thomas Lindenberger (Innsbruck: Studien Verlag, 2011), 283.

14. Ian Buruma, "The Joys and Perils of Victimhood," The New York Review of Books, April 8 (1999), 2. See also Jie-Hyun Lim, "Towards a Transnational History of Victimhood Nationalism: On the Trans-Pacific Space," in The Trans-Pacific Imagination: Rethinking Boundary, Culture and Society, ed. Naoki Sakaj and Hyon Joo Yoo (Singapore: World Scientific, 2012), 45-60.

15. Charles Maier, “A Surfeit of Memory? Reflections on History, Melancholy, and Denial," History and Memory 5, no. 2 (1993), 1936-1951. 
These warnings about the perils of a retrospective politics outweighing or even banning politics directed at contemporary injustices or striving for a more just future should be taken seriously. Yet the alternative of an exclusively present- or future-oriented politics disregarding all historical injustice is not desirable either. Contemporary injustice often manifests itself in the form of structural repetition or continuity of injustices with a long history. Moreover, totalitarian versions of progressivist politics have frequently abused the idea of a struggle for a more just future in order to justify past and present suffering. It could even be argued that the rise of dominant restrospective politics has been initiated partly on the basis of disillusionment with the exculpatory mechanisms of progressivist ideology. ${ }^{16}$ Some indeed claim that much of present-day retrospective politics and the "setting straight" of historical injustices would be unnecessary had totalitarian progressivist politics focused less exclusively on the bright future and shown more sensitivity to the contemporary suffering of its day. This claim certainly makes sense if one thinks of extreme examples such as Stalin's five-year plans and Mao's Great Leap Forward. Yet, as Matthias Frisch rightly argues, the risk of the justification of past and present suffering lurks around the corner wherever progressive logics of history or promises of bright and just futures are not counterbalanced by reflective forms of remembrance. ${ }^{17}$

Therefore, we should resist dualist thinking that forces us to choose between restitution for historical injustices and struggle for justice in the present or the future. Rather, we should look for types of retrospective politics that do not oppose but complement or reinforce the emancipatory and utopian elements in present- and future-directed politics - and the other way around: present- and future-oriented politics that do not forget about historical injustices.

In this paper I want to contribute to this goal by focusing on the issue of retrospective politics and by analyzing how one can differentiate emancipatory or even utopian types of retrospective politics from retrospective politics that I classify here as anti-utopian. I argue that the currently dominant strands of retrospective politics indeed do tend to be anti-utopian and have a very limited emancipatory potential. Moreover, I claim that currently dominant retrospective politics do not radically break with several of the exculpatory intellectual mechanisms that are typically associated with progressivist politics but actually modify and sometimes even radicalize them. In that restricted sense, and only in this sense, it can be argued that currently dominant retrospective politics do not represent a fundamentally new way of dealing with historical evil and the ethics of responsibility.

16. Thinkers such as Antoon De Baets and Samuel Moyn have also made this type of argument for human rights discourse in general. See, for example, Antoon De Baets, "A Successful Utopia: The Doctrine of Human Dignity," Historein: A Review of the Past and Other Stories 7 (2007), 71-85, and Samuel Moyn, The Last Utopia: Human Rights in History (Cambridge, MA, and London: Harvard University Press, 2010).

17. Matthias Fritsch, The Promise of Memory: History and Politics in Marx, Benjamin, and Derrida (Albany: State University of New York Press, 2005), 4. As Fritsch explains, this insight into the dangers of totalitarian versions of progressive politics formed an often overlooked background of Walter Benjamin's criticism of orthodox Marxism. See also Martin Woessner, "Reconsidering the Slaughter Bench of History: Genocide, Theodicy, and the Philosophy of History" Journal of Genocide Research 13, no. 1/2 (2011), 85-105. 
My perspective is not a pessimistic one, however. Besides the currently dominant retrospective politics, there exist other strands of retrospective politics that do have emancipatory or even utopian features and that do not force us to choose between restitution for historical injustices and struggle for justice in the present or the future. Anti-utopianism and ethical "passeism," I argue, are not inherent or necessary features of all retrospective politics but rather result from a specific, underlying type of historical thought or philosophy of history ${ }^{18}$ that treats the relation between past, present, and future in antinomic terms and prevents us from understanding "transtemporal" injustices and responsibilities. Sometimes this type of historical thought indeed stimulates a moralistic stance in which the past is charged with the worst of all evil, while the present becomes morally discharged by simple comparison. The latter type of "temporal Manichaeism" can be highly problematic, I argue, because it not only posits that the "past is evil" but also tends to turn this reasoning around and stimulates the wishful thought that "evil is past."

In order to analyze and evaluate the philosophy of history underlying currently dominant retrospective politics, I will first make an intellectual detour and start with an analysis of the philosophy of history that is typically associated with progressivist politics. In this paper I focus on an analysis by the German philosopher Odo Marquard. This "detour" is rewarding because it helps us pinpoint what the problem is with certain types of retrospective politics and how they can foreclose other forms of politics or justice. Reading the work of Marquard will also help us critically reassess the relation between classical progressivist politics and currently dominant retrospective politics.

In order to show that other more emancipatory types of retrospective politics exist, I will end this article with a brief discussion of some alternative visions of politics and justice, based on radically different notions of historicity, which have been developed by victim and survivor collectives such as the Argentine Asociación Madres de Plaza de Mayo and the South African Khulumani Support Group.

\section{ODO MARQUARD ON THE GENESIS AND PARADOXES OF PROGRESSIVIST PHILOSOPHY OF HISTORY}

The problem with progressivist philosophies of history according to Odo Marquard is that they tend to function as "secular theodicies," that is, secular versions of the old theological tradition of attempting to explain and justify the existence of evil in the world. Progressivist philosophies of history can be abused to absolve people of their responsibilities for historical evil and even to justify past and present suffering and terror. To explain why and how progressivist philosophies of history tend to turn into theodicy-like exculpatory discourses or tend to create an effect of moral unburdening (Entlastung), Marquard turns to their

18. By "philosophy of history" I am not referring to the philosophy or theory underpinning the work of professional historians. Rather, I am using the concept to refer to often widespread sets of (implicit or explicit) ideas about the process of history and the structure of historical time. 
historical genesis, which he himself describes in the form of a "grand narrative"style philosophy of history - an irony of which he seems well aware. ${ }^{19}$

According to Marquard, it is not a coincidence that modern philosophy of history - a term coined by Voltaire-came into existence around the mid-eighteenth century. The middle of the eighteenth century, according to Marquard, was an age characterized by an increased perception of evil in the world and an increasing failure of theological explanations for this evil. It is exactly this fatal combination that gave birth to modern philosophy of history. ${ }^{20}$

Still, at the beginning of the eighteenth century, Gottfried Wilhelm Leibniz had launched an influential, optimistic theological explanation for the existence of evil by claiming that all may not be good in the world, but that God created the best of possible worlds. Leibniz's theodicy - he invented the term around $1710^{21}$ - was an ingenious attempt to refute skeptical interpretations of the value of Creation and to defend God from being held responsible for the existence of evil in his Creation or at least for not putting an end to this evil. ${ }^{22}$

Leibniz's optimistic answer (Creation is the best possible one; it is optimal) may have been convincing to some for some time, but by the middle of the eighteenth century it had become increasingly unconvincing. The crisis of Leibniz's optimistic theodicy, according to Marquard, was provoked primarily by the occurrence of a series of historical calamities of which the catastrophic earthquake of Lisbon in 1755-with its ten thousands of deaths-was doubtlessly the best-known and most influential. ${ }^{23}$

In the face of evils such as the Lisbon catastrophe, no optimistic theodicy could be convincing. The problem of such a radical evil demanded a more radical answer that ultimately transcended the limits of theistic theodicy: the only way to convincingly unburden God of being held responsible for evils of this magnitude was to separate him from his Creation or even to declare his nonexistence. Marquard speaks about "Atheismus ad maiorem Dei gloriam" - "Atheism for the greater glory of God"24-and he claims that this process of theological

19. Marquard's insight into this ironic paradox is clearly indicated by the title of one of his central articles on the subject: Odo Marquard, "Beitrag zur Philosophie der Geschichte des Abschieds von der Philosophie der Geschichte," in Geschichte, Ereignis und Erzählung, ed. R. Koselleck and W. D. Stempel (Muich: Wilhelm Fink Verlag, 1973), 241-250.

20. Odo Marquard, "Die Krise des Optimismus und die Geburt der Geschichtsphilosophie," in Odo Marquard, Skepsis in der Moderne (Stuttgart, Reclam, 2007), 93.

21. Gottfried Wilhelm Leibniz, Essais de Théodicée sur la bonté de Dieu, la liberté de l'homme, et l'origine du mal. https://archive.org/details/essaisdetheodic00jaucgoog (accessed February 20, 2015).

22. It is well known that this theological problem has long plagued Christianity, which as a monotheistic religion has to answer the question why its good God allows the reign of evil in his creation. Despite the fact that "theodicy motives" have a long history in theological discussions, Marquard claims that full-blown theodicies are typically a modern phenomenon. He provocatively states that "where there is theodicy, there is modernity, and where there is modernity, there is theodicy." Odo Marquard, In Defense of the Accidental (New York: Oxford University Press, 1991), 11.

23. To illustrate how this earthquake influenced the crisis of optimism, Marquard qoutes from Voltaire's "Poème sur le désastre de Lisbonne," and to stress the magnitude of its impact on contemporary intellectual life he cites Susan Neiman's claim that the name "Lisbon" meant for those living in the eighteenth century what the name "Auschwitz" means to us. Marquard, "Die Krise des Optimismus und die Geburt der Geschichtsphilosophie," 97.

24. Odo Marquard, Schwierigheiten mit der Geschichtsphilosophie [1973] (Frankfurt am Main: Suhrkamp Verlag, 1982), 70. 
radicalization provoked the birth or at least breakthrough of secular philosophy of history. If certain intellectuals around the mid-eighteenth century started to assert humanity's autonomy (rather than its heteronomy in the hands of God) and posit its ability to make history (what Marquard aptly calls the "Vico thesis"), it was in order to protect the glory of God from being tainted by the accusation of his responsibility for the existence of evil..$^{25}$

The thesis that the rise of secular philosophy of history is the product of internal Christian theological "defects" has great implications for our interpretation of the former intellectual system and its claim about human autonomy. ${ }^{26} \mathrm{By}$ positing that humans make their own history, secular philosophy of history also makes them the "perpetrator[s] of history" [Geschichtstäter], including its evil and injustice - precisely the position that God had to be rescued from. "Humanity" inherits the position of the accused in the great philosophical "tribunal" about the existence of evil. This miserable starting position explains why philosophy of history soon develops its own (post-theist or secular) "theodicy motives," which should help "humanity" to unburden itself from its newly inherited historical responsibilities.

Marquard identifies several theodicy motives or exculpatory mechanisms in modern philosophy of history. The most important ones are the assertion of a specific notion of historical antagonism (what Marquard calls the Gegner Prinzip) and a specific temporal logic (historical progress). Taken together, the latter should ideally render (a part of) humanity morally "unindictable" for historical evil or at least provide it with the alibi of what Marquard calls Ohnmachtsgarantie (guarantee of impotence) - the alibi that one cannot be held responsible for the evil if one lacked the power to prevent or stop it.

The most obvious way to escape the accusation of being the perpetrator of evil and injustice is by identifying another perpetrator who is responsible for doing evil or for not setting it straight. If one does not want to "relapse" into accusing God or to promote "nature" to the role of "perpetrator of history" - as is all too often done, according to Marquard - this new perpetrator clearly has to be found in the immanent realm of the human. In their search for another perpetrator, Marquard argues, philosophers of history discovered the figure of the historical adversary ("den Gegner"): for example, the aristocracy, the bourgeoisie. To be sure, not every adversary can deliver an Ohnmachtsgarantie that absolves true humanity (for example, proletarians) from the burden of being responsible for

25. Marquard here turns around a more conventional analysis that interprets the philosophical assertion of human autonomy as one of the causes of the rise of atheism. See Mark Larrimore, "Autonomy and the Invention of Theodicy," in New Essays on the History of Autonomy: A Collection Honoring J. B. Schneewind, ed, Natalie Brender and Larry Krasnoff (Cambridge, UK: Cambridge University Press, 2004), 61-91.

26. Marquard does not posit the existence of a substantial historical continuity between Christian theology and secular philosophy of history in terms of their content, as, for example, Karl Löwith does in his much better known secularization thesis. Rather, he takes his inspiration from Hans Blumenberg's "functional model of history" [Funktionsmodell der Geschichte] in which historical continuity is situated in historically recurring "functions" that can be fulfilled by a great variety of intellectual systems with potentially very different (cultural, theological, and so on) content. In the case of the philosophies of history Marquard criticized, the recurring function is that of providing an answer to the age-old question of the reason for the existence of evil. 
the existence of evil in the world: only the adversary that was and is dominant, and reigned and still reigns supreme, can fulfill this function. As Marquard puts it: "in its search for exemption [Entlastung], philosophy of history needs the still unbroken dominion of the adversaries as its a priori." 27

The best way to keep a ray of hope is to represent human history as a progressive one in which a problematic past and present contrast with a good future. As a theodicy motive, the process of history itself-defined as a progression (ein Vorgang) in which some things are already done and others are still to be done $^{28}$ - offers great possibilities. More precisely, this is history in the form of a struggle between those who have done and are responsible for what is done, and those who will do and will be responsible for what still is to be done. As Marquard puts it, history can be used as a "procedure" to create a moral "division of labor" in which one group of people (that is, progressivist philosophers of history) posits itself as an avant-garde of the bright future and which as a sort of historical prosecutor is legitimated to indict the rest of humanity as a reactionary force that is responsible for the evils of the past and present. ${ }^{29}$

Yet it is clear that this arrangement to morally unburden one part of humanity by overburdening another is a dubious one, and that the radical, "neo-Manichaeist" split between absolute victims/oppressed and absolute perpetrators/ rulers or an evil past/present versus a good and bright future is untenable. Therefore Marquard proposes a departure (Abschied) from this type of philosophy of history in the name of a new moderate philosophy of history that takes human "half-heartedness" as its model and sees humanity neither as absolute perpetrator nor as absolute victim of history. ${ }^{30}$

\section{THE TRIUMPHALISM OF POST-1989 RETROSPECTIVE POLITICS}

Although Marquard, as far as I know, never explicitly discussed the subject, his plea for a departure from (progressivist) philosophy of history with its search for a moral "unindictability" and an alibi of impotence (Ohnmachtsgarantie) through an adversarial logic (Gegnerprinzip) and a neo-Manichaeist logic of historical time at first sight seems to have been realized with the rise of retrospective politics around the late 1980s and early 1990s. The rise of retrospective politics could be interpreted as a sign that "humanity," or at least the "international community," finally acknowledges that "making history" comes with responsibilities and that it can no longer be pretended that only the adversaries are responsible for evil and historical injustice in the world. This is indeed how its supporters have often presented the rise of retrospective politics. Yet I will argue that this interpretation is misleading and that it becomes unconvincing once one takes a

27. Marquard, "Beitrag zur Philosophie der Geschichte," 245 (my translation).

28. Ibid., 244 (my translation).

29. Odo Marquard, Farewell to Matters of Principle (New York: Oxford University Press, 1989), 54; see also Marquard, "Die Krise des Optimismus," 105.

30. Together with the departure from this type of progressivist philosophy of history, Marquard argues for a simultaneous rejection of forms of anthropology-criticism that posit (human) nature as the timeless source of evil. 
closer look at the ethico-political mechanisms that underpin currently dominant retrospective politics.

Retrospective policies, such as reparations and memorial programs or the issuing of public apologies, are often related to moral impulses or raised moral standards. For Trudy Govier and Wilhelm Verwoerd, for example, the international rise of the practice of "public moral apology" and the broader tendency to "take (past) wrongs seriously" should be explained as direct results of a developing "moral consensus" about human rights and, as a logical implication, a consensus that violations of human rights should not have taken place in the past either. "To apologize," they claim, "is to accept responsibility for wrongdoing, to morally acknowledge the dignity and moral worth of victims, and to commit oneself to moral reform and practical amends." 31

This moral interpretation is typically supported by highlighting the timing of the rise of retrospective politics, which is often believed to coincide with the end of the Cold War that allegedly freed many nations from their hardened adversarial logics and increased their willingness to acknowledge their own guilt. ${ }^{32}$ This explanation is, for example, given by Elazar Barkan, who claims that the fundamental innovation of post-Cold War retrospective politics is that it is based on a voluntary "embrace" of guilt by ex-perpetrators: "In a post-Cold War world we tend to pay increased attention to moral responsibility, but we do it out of choice, not necessity." ${ }^{33}$ Barkan calls this widespread recognition of moral responsibility a "neo-Enlightenment morality" because it is based on rational insight, namely a raised and democratized historical consciousness. As he puts it: "As victorious histories of the elite and the rich are replaced by the lives of the conquered, the poor, and the victimized other, the public is confronted by history as the territory of injustice. In the democratization of historical memory, the public over time encounters its own identity, one that includes immoral acts, suffering, and oppression." ${ }^{34}$ Another rational source for the rise of neo-Enlightenment morality is the growing insight that retrospective politics can serve "life" through its embrace of healing and reconciliation.

A similar stress on raised moral standards, overcoming of adversarial logics, and acknowledgment of historical guilt is often found in the broader field of transitional justice. A central feature of transitional justice's self-representation is that it contrasts its own concept of justice with that of "victor's justice," and sometimes even of retributive justice in general (as, for example, represented

31. Trudy Govier and Wilhelm Verwoerd, "Taking Wrongs Seriously: A Qualified Defence of Public Apologies," Saskatchewan Law Review 65 (2002), 161.

32. This "Cold War Thesis" often takes the form of a veritable myth of origin. Yet the claim about the temporal coincidence of the rise of retrospective politics and the end of the Cold War is not unanimously accepted. Antoon De Baets, for example, although accepting that 1989 was an important accelerator and amplifier, stresses that the genesis of the current wave of retrospective politics can be traced back to the stance of the Red Cross, which in 1974 in its protocols stressed the need to "search for the dead." Alternatively, he argues this genesis could be traced back at least to as early as 1981, with the "Quinteros case" about abductions and detentions by the military in Uruguay, or 1984, with the creation of the CONADEP truth commission after the military dictatorship in Argentina. See Antoon De Baets, Responsible History (New York: Berghahn Books, 2009), 154-163.

33. Barkan, The Guilt of Nations, xi.

34. Ibid., xxxiv. 
by the International Criminal Court), by stressing how the former results from a moral commitment to healing, reconciliation, and restoration rather than from a will for revenge or retaliation and by claiming that it generally results from internal dynamics rather than being enforced by external powers. The origins of (modern) transitional justice are almost without exception linked by its supporters to a series of internal political transitions that started with the downfall of a series of military dictatorships in Latin America, which was followed by the fall of communism in Eastern Europe and went global with the end of apartheid in South Africa and the decline of authoritarianism in countries all over the world. ${ }^{35}$ These transitions away from dictatorship or authoritarianism are typically presented as transitions toward liberal democracy: Samuel Huntington famously spoke about a "third wave" of democratization. ${ }^{36}$ Furthermore the transitions are generally presented as primarily the work of an elite of "democracy builders" - rather than, for example, resulting primarily from socioeconomic processes - who made the moral decision to respect human rights and transcend adversarial logics by breaking the cycle of vengeance and not answering violence with violence. ${ }^{37}$

The stress on reconciliation that has become such a prominent feature of transitional justice discourse and broader retrospective politics seems another proof of the downfall of philosophies of history based on the Gegnerprinzip. With its stress on reconciliation and restorative justice rather than retributive justice and rancor, transitional justice discourse at first sight seems the exact opposite of the adversarial logic criticized by Marquard. ${ }^{38}$

Does all of the above then mean that current retrospective politics has indeed finally overcome the tendency to deny responsibility for evil as it has often been seen to do in the progressive philosophies of history turned secular theodicies? Does retrospective politics' focus on historical injustice and apparent break with the Gegnerprinzip signify that it no longer searches for a moral "unindictability" or engage in secular theodicy? Is contemporary "humanity" (if this unit[y] exists) thus finally acknowledging its responsibility for evil? Regrettably, I believe the answer is no.

35. See, for example, how this narrative plays out in one of the classics of transitional justice literature, Neil Kritz's three-volume Transitional Justice (Washington, DC: United States Institute of Peace Press, 1995).

36. This new wave of democracy, according to Huntington, succeeds two earlier waves that took place after the American and French Revolutions and after the Second World War, respectively. Samuel Huntington, The Third Wave: Democratization in the Late Twentieth Century (Norman: University of Oklahoma Press, 1993).

37. Thomas Carothers, "The End of the Transition Paradigm," Journal of Democracy 13, no. 1 (2002), 1, and Paige Arthur, "How 'Transitions' Reshaped Human Rights: A Conceptual History of Transitional Justice," Human Rights Quarterly 31, no. 2 (2009), 321-367.

38. Yet it should be noticed that adversarial logic in a limited sense returns in the adversarial principle of many court cases and international tribunals (thanks to Antoon De Baets for this important remark). 


\section{RETROSPECTIVE POLITICS AND TEMPORAL "MANICHAEISM"}

Rather than breaking with the practice of secular theodicy and with the search for moral unburdening or "unindictability," I argue that dominant retrospective politics, against all appearances, actually tends to reproduce many of the intellectual mechanisms underlying older progressivist philosophies of history. Retrospective politics paradoxically makes claims about human emancipation and contemporary humanity's voluntary embrace of moral guilt but tends to produce the exact opposite effects.

I do not posit a substantial historical continuity between earlier progressivist philosophies of history (for example, Hegelian idealism; Marxism) and currently dominant retrospective politics, however. Much like Marquard, I base my claim on Blumenberg's so-called functional model of history (see note 26) and argue that progressivist philosophies of history and currently dominant retrospective politics tend to function similarly: namely, as secular theodicies.

In contrast to many progressivist philosophies of history, dominant retrospective politics does not do this primarily by indentifying concrete historical adversaries (for example, aristocracy, bourgeois, new management) who are held responsible for past and present historical injustice and for obstructing "true humanity" from reaching a more just future. Rather than explicitly referring to concrete historical adversaries-except for some iconic enemies symbolizing absolute and timeless evil, such as Fascism or communism-it radicalizes the stress on a particular temporal duality in which an increasingly abstract and decontextualized past is represented as the container and source of all evil and comes to oppose the present as the true adversary (Gegner) or the true perpetrator of history (Geschichtstäter). I will illustrate this tendency more elaborately below. Yet, as a first illustration, think of the argument of the Afrikaner member of the South African Truth and Reconciliation Commission, Wynand Malan, who in his dissenting minority position in the commission's Final Report drew to a perverted but logical conclusion the tendency toward temporal Manichaeism manifest in the findings of his colleague commissioners. As becomes clear from the citation at the beginning of this piece, Malan did this by stating that the past itself should be considered the main perpetrator and that no ethical and certainly no legal judgments should therefore any longer be made about apartheid or any of its "former" perpetrators. ${ }^{39}$

Although the radicalized Evil Past cannot be compared to the human adversary who rules supreme and literally keeps us from addressing injustice, it functions just as well, or even better, as a source of moral unburdening through the alibi of impotency [Ohnmachtsgarantie] because "common sense" knows that what has been done cannot be undone and that one ought not hold successor generations 
responsible for what their forefathers have done. ${ }^{40}$ The Evil Past of retrospective politics at first sight seems to have the disadvantage that, in contrast to the reigning adversary of progressivist philosophies of history, it cannot deliver an Ohnmachtsgarantie for evil and injustice happening in the present. In fact, however, retrospective politics actually has at its disposal a series of intellectual mechanisms that do help it to extend an Ohnmachtsgarantie to the present or at least to putatively anachronistic leftovers of the past in the present. Indeed, I argue that a major moral mechanism used to absolve contemporaries from the moral problem of present-day evil and injustice is what I call the "allochronist" historicization of these phenomena. "Allochronism" is the practice of symbolically allocating into another time phenomena that take place in the chronological present. ${ }^{41}$ The increasing stress in dominant retrospective politics on the fact that the "past is evil," regrettably often tends to result in the belief that this "evil is past" or, at least, that it is anachronistic and will become past soon. I agree with Robert Meister when he argues that one of the defining characteristics of currently dominant retrospective politics and even of recent human rights discourse in general is that it identifies itself as essentially coming after evil, and more specifically after the evil of the twentieth century ${ }^{42} \mathrm{I}$ also share Meister's worries about the ethico-political effects of such an approach. As he provocatively but very pointedly remarks, "the cost of achieving a moral consensus that the past was evil is to reach a political consensus that the evil is past." ${ }^{43}$

By allochronically historicizing contemporary injustice and treating it in terms of historical discourse, a distance is created between one's own presentday activities and these allegedly past or anachronistic crimes. Moreover, the historicizing stance also enables one to portray one's relationship to this evil in contemplative terms as analogous to that of the historian or the witness rather than of the morally more problematic position of the bystander, or worse, the beneficiary or accomplice. ${ }^{44}$ Although retrospective politics (through its stress

40. This use of the "past" as a source of Ohnmachtsgarantie is not new. Marcel Gauchet considers the cult of an original past in the form of myths of origin as the original and most perfect form of all "religion" because in contrast to later polytheistic and monotheistic religious systems, the original past as an original script, among other things, offers a perfect and nonnegotiable possibility for the radical self-dispossession of human agency or freedom and thus of responsibility. Marcel Gauchet, $\mathrm{Le}$ Désenchantement du monde: Une histoire politique de la religion (Paris: Gallimard, 1985).

41. I borrow this concept from the anthropologist Johannes Fabian. Although it seems to be perfected by dominant retrospective politics, this allochronism is not an exclusive feature of retrospective politics. Fabian actually coined the term to describe an aspect of historicist ideologies that closely resembles the progressive philosophies of history that Marquard criticizes. Johannes Fabian, Time and the Other: How Anthropology Makes Its Object (New York: Columbia University Press, 1983).

42. Robert Meister, After Evil: A Politics of Human Rights (New York: Columbia University Press, 2012), 1. As Meister argues, this self-representation is directly related to a changed conception of evil itself in recent human rights discourse: "[Evil] is no longer widely understood to be a system of social injustice that can have ongoing structural effects, even after the structure is dismantled. Rather, evil is described as a time of cyclical violence that is past-or can be put in the past by defining the present as another time in which the evil is remembered rather than repeated" (Meister, After Evil, 25).

43. Ibid., 25.

44. History, according to Hannah Arendt, is the contemplative discipline par excellence. One could say historiography represents vita contemplativa in contrast to vita activa. Hannah Arendt, "The Concept of History: Ancient and Modern," in Hannah Arendt, Between Past and Future: Six Exercises in Political Thought (New York: Viking Press, 1968) 
on restitution) seemingly tends to break with the classical modernist vision that defines the past as the realm of contemplation while considering the present and future as the realms of intervention, ${ }^{45}$ this tendency is actually strongly tempered or even neutralized by a simultaneous stress on the notions of (historical) truth and remembrance, which, as central features of a "proper" relation to the past, are generally conceived of in primarily contemplative terms.

In order to further illustrate and explain these claims, it is important to show how dominant retrospective politics is closely related to a (liberal) post-histoire philosophy of history in which the relation between past and present is typically defined in highly dualist or quasi-Manichaeist terms. As mentioned above, the rise of retrospective politics largely coincided with, or at least strongly accelerated since, the end of the Cold War and the period in which many in the West celebrated the allegedly final triumph of liberal democracy over its autocratic opponents.

The link between dominant retrospective politics and liberal-democratic posthistoire triumphalism is not just chronological but also ideological. This ideological linkage is well documented for the field of transitional justice, which, in the late 1980s and early 1990s, was developed at a series of international conferences mainly sponsored by US-based non-governmental organizations. ${ }^{46}$ Whether or not they explicitly underwrote Francis Fukuyama's famous claim about "The End of History and the Last Man, ${ }^{47}$ most transitional justice pioneers agreed that liberal democracy represented the highest stage of history in political or moral terms certainly as an ideal - and that all transitions away from authoritarianism therefore would or should logically be transitions toward this type of democracy. ${ }^{48}$

The retrospective dimensions of transitional justice were, certainly in the early days, mostly seen as necessary evils that were needed to safeguard the political transition to liberal democracy and to make sure history would not relapse into more primitive stages. Setting straight the injustices of the past, it could be said, was the burden of the Last Man living at the end of history. From its early beginnings, the "transitional" aspect of transitional justice therefore was generally given much more weight than its counterpart, "justice." This subordination of the goal of retrospective justice to the goal of transition to liberal democracy can be seen in its most straightforward form in the work of transitologist and transitional justice pioneer Samuel Huntington. Before the field of transitional justice had received its current name, Huntington identified some of its central dilemmas under the label "the torturer problem": what to do with the worst human rights

45. See, for example, Nathan Rotenstreich, Time and Meaning in History (Dordrecht: D. Reidel Publishing Co., 1987), 21.

46. For an overview of how the field of transitional justice was formed, see Arthur, "How 'Transitions' Reshaped Human Rights."

47. Francis Fukuyama, The End of History and the Last Man (London: Penguin Books, 1992).

48. For criticisms of this premise, see Carothers, "The End of the Transition Paradigm," and Hannah Franzki, "Zur Kritik von transitional justice als Projekt historischer Gerechtigkeit," Peripherie 32, no. 125 (2012), 67-81. As David Anton Hoogenboom argues, the intellectual framework underpinning transitional justice was strongly influenced by the older tradition of "transitology," which as a subfield of political science focused on regime changes after authoritarian rule and was unabashedly pro liberal democracy. David Anton Hoogenboom, “Theorizing 'Transitional Justice."” $\mathrm{PhD}$ thesis, University of Western Ontario, 2013. 
offenders of the previous regime, and how to deal with the power and support they often still have? Although his guidelines for democratizers would not be endorsed by many transitional justice scholars active today, his approach is highly representative of the currently dominant transitional justice perspective in that it starts out from the underlying idea of a fundamental and problematic temporal dualism. When a country is confronted with the question of how to treat officials who blatantly violated human rights, Huntington advised prosecution or punishment if and only if the power balance is such that the victory of liberal democracy can be guaranteed. As a general rule, Huntington advises potential "democratizers" to "recognize that on the issue of "prosecute and punish vs. forgive and forget," each alternative presents grave problems, and that the least unsatisfactory course may well be: do not prosecute, do not punish, do not forgive, and, above all, do not forget. ${ }^{49}$

The underlying post-histoire vision that strongly shaped transitional justice's perspective explains why its focus on historical injustice-even if today it is increasingly considered as a goal on its own and not merely a necessary evilhas not led to a thorough acknowledgment of responsibility for evil as our evil. Much as Fukuyama defended his thesis that liberal democracy represents the end of history primarily though a negative logic that stresses the failure, and thus the "pastness" or at least anachronism, of all political alternatives, transitional justice defends transitions to liberal democracy primarily through the negative logic of stressing the evil nature of the past. ${ }^{50}$ This explains why transitional justice programs seldom focus on the structural continuities between past and present and why their reflections on historical justice seldom lead to moral responsibility or blame spilling over into the present or to contemporary humanity. ${ }^{51}$ Since liberal democracy represents the logical and legitimate political or ethical endpoint of history and since the transition to this democracy is generally believed to have

49. Huntington, The Third Wave, 231.

50. This "negative" logic in Fukuyama's work about the anachronism of the political foes of liberalism was especially prominent in his original essay on the end of history thesis, which was published in The National Interest, where he had not yet developed his Hegelian theory about the role of thymos in political history; see Francis Fukuyama, "The End of History?," The National Interest (Summer 1989), 3-18.

51. This lack of critical scrutiny of the present and the continuities between the past and the present were, for example, often criticized in the case of the South African Truth and Reconciliation commission. South African historian Colin Bundy, for example, strongly criticized the truth commission in his country for this reason. According to him, the TRC focused too strongly on the strictly delineated period of apartheid, which it described as the "beast of the past," while it hardly took notice of continuities with the periods before and after. Colin Bundy, "The Beast of the Past: History and the TRC," in After the TRC: Reflections on the Truth and Reconciliation Commission in South Africa, ed. W. James and L. van de Vijver (Cape Town: David Philip Publishers, 2001), 9-20. Other commentators too deemed the strict focus of the TRC a missed chance for a more critical analysis of the "new" South Africa. See, for example, Jacobus Du Pisani and Kwang-Su Kim, "Establishing the Truth about the Apartheid Past: Historians and the South African Truth and Reconciliation Commission," African Studies Quarterly 8, no. 1 (2004), 77. This mechanism is not restricted to the TRC's narrative, but seems to have become a widespread way of dealing with the legacy of apartheid in South Africa. Chana Teeger and Vered Vinitzky-Seroussi argue that the South African Apartheid Museum tries to create a consensual commemoration by consistently divorcing the (dreadful) past from the (hopeful) present and by resisting narrative lines that highlight the relevance of the past to present issues and debates. C. Teeger and V. Vinitzky-Seroussi, "Controlling for Consensus: Commemorating Apartheid in South Africa," Symbolic Interaction, 30, no. 1 (2007), 57-78. 
taken place already or at least to have been initiated by the time transitional justice projects are started up, it makes little sense to pay much attention to structural continuities between past and present. Most certainly it is considered undesirable to search for inspiration in the struggle of the past, as is often done by victim and survivor groups. ${ }^{52}$

This tendency of the Evil Past to legitimize the present that seems innocent and just in comparison, thereby supplanting critical acknowledgment of contemporary responsibilities, regrettably can also be found outside the field of transitional justice in broader retrospective politics and even in mainstream Western historical culture in general. Historians have often complained about the way in which the past increasingly becomes the object of a moralistic Historia horesco referens ${ }^{53}$ and how this leads to a double moral standard in which the overburdening of the past with all the evil of the world ultimately serves to morally legitimize the present. David Lowenthal, for example, complains that although the past wasn't regarded very highly during the heyday of progressivist ideologies, today it is under assault in a different and much more moralistic way, because: "Unlike Futurists and Modernists we do not reprobate the past's material and aesthetic achievements; quite to the contrary, we cherish them. Instead, we condemn precursors' wicked misdeeds and immoral institutions. Our racist, sexist, elitist forebears are anathematized as cruel and avaricious hierarchs, and hypocrites to boot." ${ }^{54}$

The moral repudiation of the past can indeed sometimes take grotesque proportions whereby entire periods become stamped as Evil Past. The entire twentieth century, for example, as Charles Maier remarks, has been "consigned" to history, by intellectuals and the larger public alike, as a dark age of moral atrocity and absolute evil, or even simply, as Isaiah Berlin once put it, as "the worst century there has ever been." ${ }^{55}$ As Tiffany Jenkins argues, the tendency to "elevate" or "showcase" the darkest sides of mankind's history also manifests itself in many memorial museums around the world, which she therefore describes as "cabinets of misery." $" 56$

\section{PAST IS EVIL/EVIL IS PAST}

As I mentioned above, the post-histoire ideology underlying dominant retrospective politics leads to a sort of temporal Manichaeism that can obscure the

52. As Meister remarks, transitional justice and even recent human rights discourse in general increasingly turns against any notion of (revolutionary) struggle, even the notion of "justice-as-struggle" on which older post-1789 human rights discourse was based, and replaces this with a belief in the "universal innocence of past victims." Meister, After Evil, ix.

53. Lagrou, "De l'histoire du temps présent à l'histoire des autres," 13.

54. David Lowenthal, "The Past Made Present," Historically Speaking 13, no. 4. (2012), 2-6 , 4.

55. Charles Maier claims: "For Western intellectuals, the twentieth century does not refer primarily to a strictly chronological unit. Rather, it constitutes a moral epoch, a dark historical passage characterized by ideological conflict, dehumanization, wholesale political killing, unmeasured cruelty to civilians in war, and genocide." Charles Maier, "Consigning the Twentieth Century to History: Alternative Narratives for the Modern Era," American Historical Review 105, no. 3 (2000), 807-831. Berlin is cited on page 812 .

56. Tiffany Jenkins, "Memorial Museums: Cabinets of Misery," Spiked Culture (May 19, 2005). http://www.spiked-online.com/newsite/article/1044\#.VBGLvPmSwZ0 (accessed February 20, 2015). 
structural continuities between the chronological past and the chronological present and that, by means of its own version of Ohnmachtsgarantie, protects contemporary humanity from moral responsibility and blame leaking from the past into the present. Yet, as I noted, this same ideology also includes intellectual mechanics that extend this Ohnmachtsgarantie to evil and injustice happening in the (chronological) present. It does this by means of a specific politics of time that (performatively) historicizes parts of the chronological present on the basis of what one could call "typological time." ${ }^{57}$

Whoever studies Fukuyama's end-of-history thesis, for example, will notice that it is based at least as much on claims that posit the ideal or typological "pastness" of alternative forms of political rule to liberal democracy, such as theocracy or military dictatorship or fascism and communism, as on empirical proofs of the actual substantial and chronological demise or pastness of these systems of rule. ${ }^{58}$ Similarly, I have argued in previous publications that transitional justice claims about democratic victories and the overcoming of Evil Pasts are often based largely not on an observation of the actual pastness of this evil but on a politics of time that actively or "performatively" treats as past or anachronistic all those phenomena that do not conform to the liberal-democratic ideal, which is considered fully contemporaneous. ${ }^{59}$ This type of performative allochronism (active allocation in typological or symbolic time) of undesirable phenomena and persons in the chronological present can, for example, be found in truth commissions, which are at the forefront of retrospective politics. Referring to the cases of South Africa and Sierra Leone, for example, I argued that in these countries the political, social, and cultural present became so strongly defined around the values of forgiveness and reconciliation that those people (victims and survivors as well as perpetrators) who were unwilling or unable to forgive tend to be seen as living anachronisms refusing to be contemporaneous with the rest of the nation.

57. Fabian, Time and the Other.

58. Fukuyama often makes use of an allochronist discourse when dealing with these alternative ideologies and political systems, calling them, for example, "primitive," "stuck in history," "traditional," or "anachronistic." Take, for example, the following passage about the historical status of communism: "China, of course, continues to be ruled by a communist government, as do Cuba, North Korea, and Vietnam. But . . . those who call themselves communist now find themselves fighting continuous rearguard actions to preserve something of their former position and power. Communists now find themselves in the unenviable position of defending an old and reactionary social order whose time has long since passed, like the monarchists who managed to survive into the twentieth century." Fukuyama, The End of History and the Last Man, 35-36. Whenever Fukuyama encounters examples of cases where these ideological alternatives seem all too vital to declare them dead and gone, Fukuyama pulls the idealist card and questions whether these cases have any universal historical importance. Fukuyama in his original essay, for example, notoriously claimed that for the purpose of proving his thesis, "it matters very little what strange thoughts occur to people in Albania or Burkina Faso, for we are interested in what one could in some sense call the common ideological heritage of mankind." Fukuyama, "The End of History?"

59. Berber Bevernage, History, Memory, and State-sponsored Violence: Time and Justice (New York: Routledge, 2012), and Berber Bevernage, "Writing the Past Out of the Present: History and the Politics of Time in Transitional Justice, History Workshop Journal 69, no. 1 (2010), 111-131. I recently felt confirmed in my conviction about the pervasiveness of this mechanism of performative allochronism and the mechanism of the "past is evil/evil is past"-inversion by reading Meister's impressive book on what he calls the politics of human rights discourse. See Meister, After Evil. 
Once one comes to identify this moral mechanism, one can find many examples of this strategy that not only tends to conceive of the past as evil but also turns this reasoning around and tends to historicize or "anachronize" evil whenever it encounters it. Often this mechanism is quite innocent. Take, for example, the Belgian campaign against littering that paradoxically tries to relegate to the past this clearly very contemporary problem by putting up posters claiming that "littering is no longer of this time" ["Zwerfvuil is niet meer van deze tijd"] ${ }^{60}$ Or take the example of former French president Sarkozy, who in 2010 visited the village L'Aiguillon-sur-Mer that was heavily damaged by a storm and who immediately historicized this calamity and accordingly took a distancing, contemplative stance by exclaiming that this is "unacceptable" in "the twenty-first century" and by demanding an inquiry delivering "full clarity." ${ }^{61}$ A less innocent example of this mechanism is given by Paul Ricoeur, who, referring to the fate of Holocaustsurvivor testimonies, writes, "so inadmissible to the ordinary understanding of their contemporaries appear the extraordinary events on which they report, and which therefore look even more 'bygone' than any and all abolished past, that the voices of these witnesses are often inaudible-sometimes they die of the incomprehension they encounter." ${ }^{\prime 2}$ Or take the example given by Inés Vázquez, an Argentine intellectual connected to the Madres de Plaza de Mayo. She complains that the contemplative and historicizing discourse of remembrance has become so influential that the demand for remembrance appears immediately, practically attached to crimes, and that human rights activists often start to "remember" even in situations where "temporal logic" clearly demands "perception and action." Vázquez illustrates her claims by narrating the case of the Argentine reporter José Luis Cabezas, who was murdered on Sunday, January 25, 1996, and for whom protesters two days later were already shouting, "let's not forget about Cabezas." ${ }^{33}$ Or take the implicit example of $\mathrm{CNN}$, compelled to explicitly name its anti-slavery project "Ending Modern-day Slavery" in order to fight the stubborn, common habit of associating slavery exclusively with the Evil Past. ${ }^{64}$

60. A similar, but clearly more self-conscious, use of this technique of performative allochronism was recently used in another advertising campaign, this time in one of Belgium's major papers, on the topic of female circumcision. Against an empty white background the ad centrally features the word "vrouwenbesnijdenwas" (transliterated "circumcizingwomenwas"). At the bottom of the ad a smaller text frame adds some extra explanation under the slogan "Make female circumcision past tense" ("Maak vrouwenbesnijdenis verleden tijd").

61. Website of Flemish Radio and Television, De redactie.be (March 1, 2010).

62. Paul Ricoeur, "Temporal Distance and Death in History," in Gadamer's Century: Essays in Honor of Hans-Georg Gadamer, ed. Jeff Malpas, Ulrich Arnswald, and Jens Kertscher (Cambridge, MA: MIT Press, 2002), 245.

63. Ines Vázquez, "Aspectos de Memoria y Cultura en la Argentina postdictatorial," in Un país. 30 años. El pañuelo sigue haciendo historia, ed. I. Vázquez and K. Downie (Buenos Aires: Ediciones Madres de Plaza de Mayo, 2006), 201-217. [my translation]

64. See http://thecnnfreedomproject.blogs.cnn.com/ (accessed February 23, 2015). Francis Fukuyama describes how the Encyclopedia Britannica of 1910-11 under the heading of "torture," explained that "the whole subject is one of only historical interest as far as Europe is concerned." Fukuyama, The End of History and the Last Man, 4. 


\section{CONCLUSION: TOWARD ALTERNATIVE PHILOSOPHIES OF HISTORY}

Having identified some of the problems plaguing dominant retrospective politics, what alternative can be proposed? Some would undoubtedly recommend simply quitting the project of historical justice and leaving the past for what it is or even trying to forget about its evils. This advice is not always based on cynical motives and is sometimes given out of a genuine interest in emancipation and justice or at least conflict resolution and reconciliation. ${ }^{65}$

Yet I do not believe that abandoning the project of historical justice is a desirable or necessary solution to the problems of current (post-utopian or even post-political) politics in general or, more specifically, the problems of a historical culture threatening to turn into a "liturgy celebrating the superiority of the present" ${ }^{66}$ - even if these problems are undeniably very real.

The problem with dominant retrospective politics - its anti-utopian character and its tendency to create a double standard-should not be situated in the fact that it focuses on the past per se, but rather should be related to a specific underlying philosophy of history that is based on a specific antinomic or even dualist vision of temporality that opposes the past to the present and the future and tends to be used for a specific function: that of a secular theodicy that exculpates us contemporaries in relation to chronologically past as well as chronologically present evils and injustice. As I have argued by referring to the work of Odo Marquard, simply substituting retrospective politics for progressive politics cannot be the solution because a similar exculpatory mechanism is also found in progressivist philosophies of history, which for this purpose make use of a temporal dualism as well (one opposing past and present to the future).

A radical break with these types of exculpatory mechanisms, then, can only be achieved if we break with that which both dominant retrospective politics and (totalitarian) progressivist politics have in common: their specific concept of historical time that conceives of the temporal dimensions of past, present, and future in antinomic or even "dualist" terms and treats them as discrete and mutually exclusive entities. What is needed is a radically different philosophy of history

65. Jean Bethke Elshtain, for example, defends resorting to a "knowing forgetting" in situations where nations or groups are held hostage to a burdened past and are in great need of the "drama of forgiveness." "People," she writes, "are very fond of citing Santayana's claim that those who don't know their history are doomed to repeat it. But perhaps the reverse is more likely, namely, that it is those who know their history too well who are doomed to repetition." Jean Bethke Elshtain, "Politics and Forgiveness," in Burying the Past: Making Peace and Doing Justice after Civil Conflict, ed. N. Biggar (Washington, DC: Georgetown University Press, 2001), 43. Ashis Nandy criticizes the idea that remembrance always is superior to forgetting as a typically modern Western bias and claims that Indian society has a notion of "principled forgetfulness" that can be of great importance for conflict resolution. Ashis Nandy, "History's Forgotten Doubles," History and Theory, Theme Issue 34 (1995), 44-66. On a more personal level Jorge Semprún attributed his survival after Buchenwald to "a long cure of aphasia, of voluntary amnesia, in order to survive." Cited in A. G. Loureiro, The Ethics of Autobiography: Replacing the Subject in Modern Spain (Nashville, TN: Vanderbilt University Press, 2000).

66. Lagrou, "De l'histoire contemporaine à l'histoire de l'autre," 116 [my translation]. 
that rethinks historical temporality in such a way that it no longer lends itself to these types of antinomic or dualist figures of thought. Only on this basis can we create a more substantial and inclusive project of historical justice that does not force us to choose between retrospective justice, on the one hand, and justice in the present or the future, on the other, but makes these reinforce each other.

I do not have the space here to discuss in detail the quest for such an alternative philosophy of history. In previous publications I have argued that several thinkers - Louis Althusser, Ernst Bloch, Johannes Fabian, but most notably Jacques Derrida with his notion of "spectrality" - have proposed alternative ways of thinking about history and temporality that can offer good starting points for such a quest. ${ }^{67}$ Yet a good "practical" starting point for this quest is to look at the alternative visions of historical time that many victims' and survivors' groups hold. Their visions are not at all identical to that of the dominant retrospective politics. A common feature of groups such as the Argentine Madres de Plaza de Mayo, the South African Khulumani Support Group, groups in Sierra Leone, or even groups in China is that they often $d o$ combine their retrospective gaze with present- and future-focused projects of justice (for example, redistributive justice) and that they therefore resist dualist visions of temporality and even notions of temporal distance.

The South African Khulumani Support group states in one of its manifestoes, "victims and survivors declare the past to be in the present." ${ }^{68}$ This idea fits very well with the basic philosophy of history of, for example, the Argentine Madres, who after more than thirty years still claim that the disappearance of their children does not belong to the past. In a more complex way it also relates to the vision of history of rural groups in China, which, according to anthropologist Erik Mueggler, responded to the violence of the Cultural Revolution and the Great Leap Forward by re-engaging with forms of ancestor-worship that openly rebelled against the linear progressive time coming from Beijing. ${ }^{69}$

The stance of these victims' groups seems to make them especially vulnerable to the mechanism of what I called allochronist historicization, but actually, if successful, it can also subvert this mechanism by rejecting the idea of past, present, and future as discrete and mutually exclusive categories. Following the lead of these activist groups, I have argued that philosophers of history should break with the idea of the fully contemporaneous present and instead embrace that of radical noncontemporaneity or noncoevalness. ${ }^{70}$ This idea is radical because, if consistently thought through, it forces us to break with the idea of past, present, and future as separate ontological unities - rather than just chronological demarcations. It is also radical because it forces us to break with something that is valued

67. Bevernage, History, Memory, and State-sponsored Violence.

68. Khulumani Support Group, "Khulumani Case in New York's Second Circuit Court of Appeals from January 24, 2006," November 15, 2007. http://www.khulumani.net/khulumani/statements/ item/180-khulumani-case-in-new-yorks-second-circuit-court-of-appeals-from-january-24-2006.html (accessed February 23, 2015).

69. Erik Mueggler, "Spectral Subversions: Rival Tactics of Time and Agency in Southwest China," Comparative Studies in Society and History 41, no. 3 (1999), 458-481.

70. See Berber Bevernage, "Against Coevalness: An Engaging Critique of Johannes Fabian's Analysis of the Politics of Time," unpublished paper. 
very dearly by many progressive intellectuals: namely, the idea that the basis of critical thought is to ask "what time" we are living in, to think the "present" and "actuality" or the injunction to "Always historicize," "1 to quote Fredric Jameson. Once one breaks with the idea of past, present, and future as discrete ontological entities and embraces the idea of radical noncontemporaneity, one can indeed no longer say what is truly "of this time," what is truly progressive and pointing to the future, or what really belongs to the past and whose defense is thus conservative or even reactionary.

Yet I am convinced that the idea does not at all prevent us from reflecting critically on society. On the contrary: Rather than try to say what time it is, one has to focus on the active and dynamic process of "timing" or "temporalization." A critical analysis of the politics of time should focus on how groups performatively create hegemonic "contemporaneities" (for example, the modern West as truly contemporaneous, as representing the contemporary ${ }^{72}$ ) and how they try to stamp other groups and phenomena as future or past. Such an analysis should also focus on how hegemonic and counter-hegemonic groups try to enforce closure upon or keep alive certain spaces of experience and how they try to open up or foreclose certain horizons of expectation (to use Koselleck's terminology). In the words of Jacques Rancière, we have to analyze how time and, more specifically, the separations between past and present are used as a "principle of impossibility." 73 Moreover, an embrace of radical noncontemporaneity has the advantage that we can find utopian potential in what is commonly considered to be the future, the present, and the past. In this vision, retrospective politics indeed does not at all need to oppose emancipatory or utopian politics but can reinforce and reinvigorate them.

\section{Ghent University}

71. Frederic Jameson, The Political Unconscious: Narrative as a Socially Symbolic Act (Ithaca, NY: Cornell University Press, 1981), 9.

72. For a very insightful analysis of the historical category of "the contemporary" and its political implications, see Peter Osborne "Global Modernity and the Contemporary: Two Categories of the Philosophy of Historical Time," in Breaking up Time: Negotiating the Borders between Present, Past and Future, ed. Chris Lorenz and Berber Bevernage (Göttingen: Vandenhoeck \& Ruprecht, 2013), 69-84.

73. Jacques Rancière, "In What Time Do We Live?," Política Común 4 (2013). http://quod.lib. umich.edu/p/pc/12322227.0004.001/--in-what-time-do-we-live?rgn=main;view=fulltext (accessed February 23, 2015). 